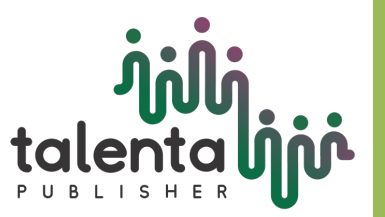

\title{
Supplementation of Cassava Leaf (Manihot Esculenta Crantz) in Field Grass in Sheep Growth
}

\section{Andhika Putra and Wawan Setiawan Sinaga}

Animal Husbandry Study Program, Faculty of Sains and Technologi, Universitas Pembangunan Panca Budi, Indonesia

\begin{abstract}
Supplementation of cassava leaves (ManihotesculentaCrantz) in the base grass field ration of male rams in the growth period aims to determine the effect of giving cassava leaves to the performance of sheep, parameters measured in this study were consumption level, body weight gain and feed conversion in local sheep in the growth period. This study used randomized complete design (CRD) 4 treatments and 6 replications. Using male local sheep with an average body weight of $\bar{X}=12 \pm 1.93$. The treatment used $\mathrm{T} 0=$ without giving cassava leaves $(\mathrm{Control}), \mathrm{T} 1=25 \%$ cassava leaves, $\mathrm{T} 2=50 \%$ cassava leaves, T3 $=75 \%$ cassava leaves. The results of the study with variance analysis showed no significant effect ( $p>0.05)$ feed consumption level, body weight gain and feed conversion ratio the conclusion of this study is the supplementation of cassava leaves (ManihotesculentaCrantz) on grass-based rations did not provide a different growth increase in weaning local male sheep.
\end{abstract}

Keywords: cassava leaves, growth, sheep

Received 10 November 2018 | Revised 28 January 2019 | Accepted 02 February 2019

\section{Introduction}

Sheep has the potential and opportunity to be developed because it easy maintenance and can mate naturally. Other main potentials are meat and manure as a meat producer, this feed is an alternative meat for the community, especially on the feast of Qurban, marriage, wedding parties and the needs of rice stalls/restaurants, both as traditional and semi-modern preparations.

The contribution of sheep business to the agricultural sector is still below 30\% [1] business countries are only supporters of commodities and are classified as intermittent business. Likewise, it is currently very difficult to cultivate abroad as well as $5 \%$. While poultry meat reaches $56 \%$, beef is $23 \%$, pork is $13 \%$.

One of the important factors in ruminant farming is continuous feed throughout the year with adequate quality. The problem that often occurs in the tropics is the creation of things that are limited during the dry season and difficult to obtain both quality and quantity. This situation

*Corresponding author at: Animal Husbandry Study Program, Faculty of Sains and Technologi, Universitas Pembangunan Panca Budi, Jl. Jend. Gatot Subroto KM 4,5, Medan, 20122, Indonesia

E-mail address: Andhikaputr@dosen.pancabudi.ac.id 
often causes livestock production to be low. Forage cassava leaves in the field as a supplement food ingredient. In an effort to grow livestock, it should be noted that the feed is done by adding food ingredients that are high in protein to the ration, which can provide nutrients to the body [3].

Many breeders are hesitant in using cassava leaves as sheep's feed given the cyanide content that is identical to poisons. The method is easy, before the leaves are given cassava leaves drying / drying is then given to the sheep. Drying can reduce levels of Cyanide Acid (HCN) by up to $90 \%$ [4].

Cassava leaves had a high crude protein content which was between $25.23 \%$, dry matter around $24.27 \%$ and almost $85 \%$ of the crude protein fraction was pure protein [5]. Furthermore, the use of cassava leaves in the ration formulation can be used as protein and concentrates in goats, sheep and cattle [6].

Based on the description above, the author would like to discuss the research on Supplementation of Cassava Leaves (ManihotesculentaCrantz) in the Basic Ration of Field Grass on the growth of male local sheep Growth Period.

\section{Materials and Methods}

\subsection{Materials}

This research was conducted in Senayan Village, Sei Rampah Subdistrict, Serdang Bedagai District, North Sumatra Province. The materials used in this study were 24 male local weaning with an average body weight of $\bar{X} \pm \mathrm{SD}=12 \pm 1.93$. Cassava leaf ration as feed treatment, field grass as basic feed, equipment used in this study include cages, feeder, scales, stationery and lighting.

Cassava leaves were obtained from the harvesting of cassava around the research area, precisely in the village of Sei Rampah, the cassava leaves were laid out by drying in the sun for one day then cassava leaves were stored in a storage container to reduce the Hcn content contained in the leaves the cassava. Then cassava leaves can be given to livestock according to the needs that have been determined.

\subsection{Methods}

This study used Completely Randomized Design (CRD) non-factorial consist of 4 treatments with 6 replications. The treatment given as follows:

$\mathrm{T} 0=$ Grass $(\mathrm{a} d$-libitum $)$

$\mathrm{T} 1=$ Field Grass $(\mathrm{a} d$-libitum $)+25 \%$ Cassava Leaf 
$\mathrm{T} 2=$ Field Grass $(\mathrm{a} d$-libitum $)+50 \%$ Cassava Leaf

$\mathrm{T} 3=$ Field Grass $(\mathrm{a} d$-libitum $)+75 \%$ Cassava Leaf

\subsection{Procedures}

The procedure carried out in this study was to use 24 local male sheep then weighed and recorded their body weight and put into each trial cage as many as 24 plots equipped with a feeding place, drinking place and lighting with randomly according to randomization treatment. Feeding is carried out at 09.00 AM and 18.00 PM. feed is weighed and recorded before being given to livestock and the remaining feed is weighed and recorded as remaining consumption then calculated to obtain daily consumption data. Weighing sheep is carried out and recorded every month and deducted by the difference between the last weighing and the previous weighing to obtain data on body weight gain. Total consumption data is divided by total body weight gain data to obtain data on animal feed conversion ratio.

\subsection{Observed Variables}

\section{A. Feed consumption (g/head/day)}

Ration consumption data obtained by weighing feed given for a day, then reduced by weighing the rest of feed for one day.

$$
\text { Consumption feed }=\text { Initial feed }- \text { Final feed }(\text { gram })
$$

\section{B. Increase of body weight (g/head/day)}

The weight gain data is obtained by each weighing week which is the difference between weighing the final body weight with weighing the initial weight of unity of time (grams/weeks).

The weight gain body $=$ weight of final weight - initial weight

\section{Feed conversion ratio (FCR)}

The feed conversion data is calculated every month by the way comparing the amount of feed (grams) consumed by increasing body weight (grams) every month.

Convert feed $=$ Consumption of feed $(\mathrm{g} /$ head/day) / Increase of Body Weight (g/head/day)

\section{Results and Discussion}

The results on body weight gain, feed consumption and feed conversion showed different results not significantly seen in Table 1. 
Table 1. Supplementation of Cassava Leaf (ManihotEsculentaCrantz) in Field Grass in Sheep Growth

\begin{tabular}{cccc}
\hline \multirow{2}{*}{ Treatment } & \multicolumn{3}{c}{ Average (g/head/day) } \\
\cline { 2 - 4 } & $\begin{array}{c}\text { Body Weight Gain } \\
\text { (g/head/day) }\end{array}$ & $\begin{array}{c}\text { Feed Consumption } \\
\text { (g/head/day) }\end{array}$ & Feed Conversion \\
\hline T0 & 92,14 & 749,66 & 8,14 \\
T1 & 99,92 & 806,12 & 8,07 \\
T2 & 108,15 & 875,23 & 8,09 \\
T3 & 105,79 & 824,78 & 7,80 \\
\hline
\end{tabular}

\subsection{Feed Consumption (g/head/day)}

The results showed that the level of consumption contained in the treatment of T3 (field grass + $75 \%$ cassava leaves) with the highest feed consumption value of $875.23 \mathrm{~g} /$ head / day, while the treatment of T0 (field grass) for the lowest level of body weight and consumption, where the consumption value is $749.66 \mathrm{~g} /$ head / day and body weight gain is $92.14 \mathrm{~g} /$ head / day. The addition of cassava leaves to elephant grass given to sheep can increase the amount of consumption and body weight [7].

The level of animal feed consumption is influenced by the quality of animal feed provided, the higher the quality of animal feed, the higher the level of consumption, cassava leaves have a fairly good quality as animal feed. Report that the crude protein content of cassava leaves reaches $27.97 \%$ which is quite good as animal feed. From the results of the study it was seen that the increase in feed consumption was in line with the increase in the supply of cassava leaves to the level of $50 \%$ [8]

Important factors that influence sheep growth include food, genetics, sex, health, and management. broadly can be separated into genetic and environmental factors. Genetic factors are higher than expected. Environmental factors such as conservation, feed, challenge or eradication of disease and governance will determine the level of growth in adult achievement [9].

Giving cassava leaves to livestock has limitations because the anti-nutrient content of cassava leaves is HCN and tannin. Cassava leaves contain cyanide compounds of around $253 \mathrm{ppm}$ at high concentrations which are very toxic and can kill livestock. Cyanide content in leaves is much higher around 2.6 - 27.3 times compared to the tuber [10].

The results of the study showed that cassava leaves were boiled for 45 minutes in order to isolate the substances they contained. These cassava leaves that have been boiled for 45 minutes, the HCN content drops to $98.5 \%$. [12] reported that sheep were able to tolerate cyanide acid at a concentration of $2.5-4.5 \mathrm{ppm}$ per $\mathrm{kg}$ of live weight, the concentration of cyanide acid that was safe from toxic effects was below $30 \mathrm{ppm}$. The high content of cyanide in cassava 
leaves can cause poisoning if consumed by livestock (sheep / goats). This contained cyanide can endanger livestock if it is contained in feed ingredients given in doses that exceed the limit.

\subsection{Average Body Weight}

The results of the statistical analysis showed significant effect on average daily weight. The average daily body weight gain was the best in the $\mathrm{T} 2$ treatment $(50 \%$ addition of cassava leaves) with the level of giving cassava leaves as much as $108.15 \mathrm{~g} /$ head / day and the lowest body weight gain was found in the Po treatment (control) ie $92.14 \mathrm{~g} /$ head / day. study using field grass, corn leaves, corn husk and complete ration as feed, which ranged from 92.86 $128.18 \mathrm{~g} / \mathrm{head} /$ day.

The results of the study showed that the addition of cassava leaves in the sheep feed experienced an increase in body weight although the statistical tests did not show different results. This is because cassava leaves contain nutrients that are quite good as animal feed with a crude protein content of $27.97 \%$ [8]

The weight gain of ruminants is strongly influenced by the quality and quantity of feed, this is meant by the assessment of animal weight gain comparable to the ration consumed. Added that, one of the factors that influence body weight gain is feed consumption, the higher the amount of feed consumed, the higher the growth rate of livestock [9].

\subsection{Feed Conversion}

The ration conversion was calculated by comparing the amount of ration consumed with the body weight gain gained every week. Feed conversion is strongly influenced by livestock conditions, livestock digestibility, gender, nation, quality and quantity of feed, also environmental factors The best ration conversion is found in $\mathrm{T} 3$ treatment ( $75 \%$ cassava leaves) which is equal to 7.80, while the highest ration conversion is in treatment $\mathrm{T} 0$ (control) that is equal to 8.14 .

To determine the effect of using cassava leaves on feed conversion of rams, variance analysis was carried out. The results of variance analysis showed not significant effect. This study using sheep in all treatments, influenced by age, type of sheep, which were used during the same study.

This is in accordance with what was stated by that conversion is influenced by a number of factors such as: age of livestock, nation, nutritional content of rations, temperature and health conditions [13]

Feed conversion is one of the benchmarks for assessing the ability of livestock to remodel feed into meat products. Feed conversion is a comparison between the amount consumed at a certain time and the production produced (body weight generated) in the same time period. The results 
of variance analysis show different results that are not real. Although there are differences in conversion rates, this does not affect the results of variance analysis

Feed ingredients are the most basic life needs, growth, and other bodily functions, as well as the types of feed ingredients consumed. According to [11], feed conversion is used to see the efficiency of feed use by livestock or it can be said that the efficiency of changing feed into the final product is the formation of meat.

\section{Conclusion and Recommendation}

The results showed that the use of cassava leaves (ManihotesculentaCrantz) as sheep feed give significant effect on feed consumption and body weight gain by using $50 \%$ in feed. Giving cassava leaves to sheep as feed can be used to $50 \%$ in feed. By using a drying treatment for 1 day to reduce the content of $\mathrm{HcN}$ in cassava leaves.

\section{REFERENCES}

[1] S. Mulyono, Teknik Pembibitan Kambing dan Domba. Jakarta: Penebar Swadaya, 2003.

[2] Direktorat Jenderal Peternakan, "Kebijakan operasional dan rencana kegiatan subsektor peternakan," Jakarta, 2003.

[3] E. Purbowati, C. I. Sutrisno, E. Baliarti, S. P. S. Budhi, and W. Lestariana."Pengaruh pakan komplit dengan kadar protein dan energi yang berbeda pada penggemukan domba lokal jantan secara feedlot terhadap konversi pakan", Bogor: Badan Penelitian dan Pengembangan Pertanian, Departemen Pertanian, 2007.

[4] M. Wanapat, "Role of cassava hay as animal feed in the tropics," International Workshop Current Research and Development on Use of Cassava as Animal Feed, KhoKaen University, KhoKaen, 2001.

[5] Hartutik, "Pengaruh tingkat penggunaan silase hijauan ketela pohon (ManihotesculentaCrantz) dengan penambahan aditif dalam ransum terhadap penampilan kambing," Malang: Fakultas Peternakan, Universitas Brawijaya, 2005.

[6] L. D. Ngoan, "Using cassava roots and leaves for on farm animal feeding in Vietnam," Faculty of Animal Science, Hue University, Hue, 2005.

[7] A. Djajanegara, W. Mathius, and M. Rangkuti, "Pengaruh penambahan daun singkong (manihot utilisima pohl) dalam ransum kambing," Ilmu dan Peternakan, vol. 1, no. 3, pp. 99- 102, 1983.

[8] H. Fukuba and Emt. Mendoza, "Determination of cyanide in cassava" Tropical Root Crop Postharvest Physiology and Processing," Japan Scientific Societies Press, Tokyo, 1984.

[9] Yuningsih. "Perlakuan penurunan kandungan sianida pada ubi kayu," Jurnal Penelitian Pertanian Tanaman Pangan," Bogor: Pusat Penelitian dan Pengembangan Peternakan, 2009.

[10] Mathius and A. P. Sinurat. "Pemanfaatan bahan pakan inkonvensional untuk ternak," Balai Penelitian Ternak, vol. 11, no. 2, Bogor, 2001.

[11] Firki, "Pemberian biskuit limbah tanaman jagung dan rumput lapang terhadap konsumsi dan pertambahan bobot badan domba ekor tipis," Skripsi, Fakultas Peternakan, Institut Pertanian Bogor, Bogor, 2010. 
[12] T. Sutardi, Landasan Ilmu Nutrien. Bogor: Departemen Ilmu Makanan Ternak IPB, 1990.

[13] G. Gomez and M. Valdivieso, "Cassava foliage: chemical composition, cyanide content and effect of drying on cyanide elimination," Journal of The Science of Food and Agriculture, no. 36, pp. 433-441. 